\title{
Resistivity mapping in the Tatun Volcano Group, Northern Taiwan, revealed by VLF-MT surveys
}

\author{
Shogo Komori ${ }^{1, *}$, Mitsuru Utsugi ${ }^{2}$, Tsuneomi Kagiyama ${ }^{2}$, Shin Yoshikawa ${ }^{2}$, Chang Hwa Chen ${ }^{3}$, and \\ Benjamin Fong $\mathrm{Chao}^{3}$ \\ ${ }^{1}$ Geological Survey of Japan, National Institute of Advanced Industrial Science and Technology (AIST), Ibaraki, Japan \\ ${ }^{2}$ Aso Volcanological Laboratory, Kyoto University, Kumamoto, Japan \\ ${ }^{3}$ Institute of Earth Sciences, Academia Sinica, Taipei City, Taiwan
}

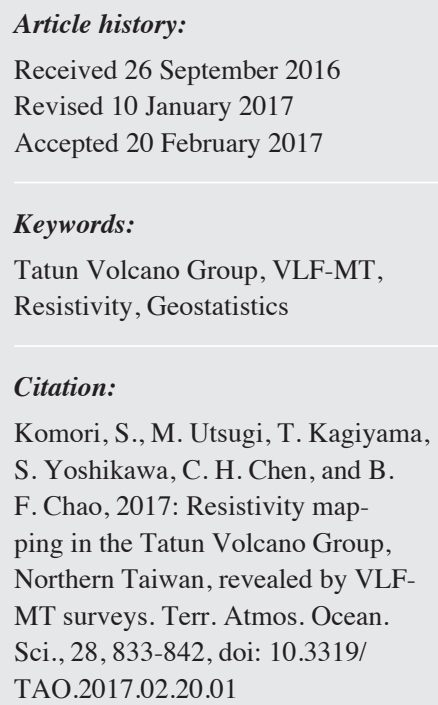

\begin{abstract}
In a volcanic region, unstable conditions of the surface geology result in natural hazards such as landslides. The present study aims to examine the properties of the formation near the surface in the Tatun Volcano Group (TVG), Northern Taiwan. Dense Very Low Frequency magnetotelluric (VLF-MT) surveys were conducted to obtain the near-surface resistivity. A geostatistical approach and stochastic simulation were used to examine the continuity of the data, and to render the spatial distribution of the resistivity. The results show that the estimated range is consistent with the length scale of the geological features such as the hydrothermal phenomena and volcanic edifices. The estimated distribution of the resistivity successfully identified a fresh lava ( $\geq 1000 \Omega \mathrm{m}$ ), a lineament-bearing, weathered lava ( $\leq$ a few hundred $\Omega \mathrm{m})$, and hydrothermal areas $(\leq 30 \Omega \mathrm{m})$. On the basis of the present study, we expect further detailed geophysical investigations will be performed from the viewpoint of hazard mitigation in the TVG.
\end{abstract}

\section{INTRODUCTION}

Geophysical exploration has been widely used for delineation of underground structure all over the world, for instance, to assess potential natural hazards (Jongmans and Garambois 2007), to monitor the groundwater conditions (Fitterman and Stewart 1986), and to exploit mineral and energy resources (Waters 1987). Particularly in Taiwan, there are increasing numbers of geophysics-based explorations programs for disaster investigation and mitigation (Chang et al. 2012). Volcanic activity is one of the potential sources of disasters in Northern Taiwan, where there is an active volcanic region, the TVG.

Resistivity is one of the geophysical parameters that can effectively visualize the shallow structure in a volcanic region, because it has a great sensitivity to cracks filled with fluids, rock alteration, and hydrothermal activity, which are characteristics of the region (Stanley et al. 1976; Benderitter

\footnotetext{
* Corresponding author

E-mail: komori.shogo@aist.go.jp
}

and Gérard 1984; Ogawa et al. 1998; Komori et al. 2013a). In the present study, an electromagnetic method was applied to reveal the resistivity distribution in the TVG. The distribution was compared with the geological features in order to examine the distribution of hydrothermal phenomena and the properties of the surface lithology.

\section{SITE DESCRIPTION - TVG}

The TVG is located on the northern tip of Taiwan Island, covering an area of $\sim 300 \mathrm{~km}^{2}$ and overlying Tertiary basement, as shown in Fig. 1 (Chen and Wu 1971; Wang and Chen 1990). Significant magmatism occurred in response to the complex tectonic activity caused by the postcollisional processes involving the Philippine Sea Plate and the Eurasian Continent, and the opening of the Okinawa Trough (Wang et al. 1999; Chang et al. 2003; Shyu et al. 2005; Chen et al. 2010). Two major NE-SW trending faults, known as the Chinshan and Kanchiao Faults, were also 
developed under the above tectonic regime. The present extensional stress field in the area has resulted in a half-graben structure developing between the faults (Shyu et al. 2005).

The TVG is composed of two volcanic trends; an older NE-SW volcanic trend and a younger E-W trend (Belousov et al. 2010). In the NE-SW trend, the edifice has steep cliffs and deep valleys caused by prolonged weathering. In contrast, the shape of the domes and cones, and their collapses in the E-W trend are well preserved, as represented by Mt. Chishin, Mt. Shamao, Mt. Datun, and Mt. Huangzuei. The domes and cones are composed of weakly to moderately vesiculated, andisitic lava (Belousov et al. 2010). At the foot of these mountains, there are active hydrothermal vents such as Beitou, Siao-you-keng, Matsao, and Da-you-keng, indicating that the TVG has potentially active heat and/or magmatic sources below the surface (Yang et al. 1999, 2003; Lee et al. 2005; Ohba et al. 2010; Liu et al. 2011; Ohsawa et al. 2013). In addition, hot springs are also present in the limited area of the coastal strip of the Chinshan District.

Previous electromagnetic surveys have been carried out to investigate the underground resistivity structure in the area (MRSO 1969, 1970, 1971, 1973; Chen et al. 1998; Chen 2009; Chen and Huang 2014; Komori et al. 2014). In particular, Komori et al. (2014) performed audio-magnetotelluric (AMT) surveys under a thematic research project called "Understanding the Life of the Tatun Volcanic Group: Integrated Analysis of Geophysical, Geochemical and Geodetic Observations" (http://www.earth.sinica.edu. tw/res project e.php). The surveys showed the hydrother- mal activity in detail, with a combination of the resistivity structure and other geodetic and geochemical studies. While these studies targeted the hydrothermal system beneath the TVG in a "vertical" direction, the present study will first focus on the "lateral" variations in rock properties (i.e., weathering, alteration, and fracturing) and hydrothermal phenomena near the surface, by performing the dense VLFMT survey described below.

\section{VLF-MT SURVEYS}

VLF-MT is based on the principle of magnetotellurics (MT) (Cagniard 1953; Vozoff 1991; Simpson and Bahr 2005), which utilizes an induction phenomenon of VLF waves emitted from the center of a transmitter. The propagating wave principally induces a radial electric field and a tangential magnetic field with respect to the transmitter (Tabbagh et al. 1991), and these are measured by a receiver deployed in the far field region to calculate the apparent resistivity and phase. The VLF-MT is effective in estimating near surface formation resistivity at depths of tens to a hundred meters, making it possible to compare the calculated resistivity with surface geological features (Yamaguchi et al. 2001). Furthermore, VLF-MT survey can be conducted in a very short time (typically less than ten seconds per measurement, depending on data stacking), enabling spatiallydense surveys to be carried out compared to conventional MT observations.

In the present study, the VLF-MT surveys were

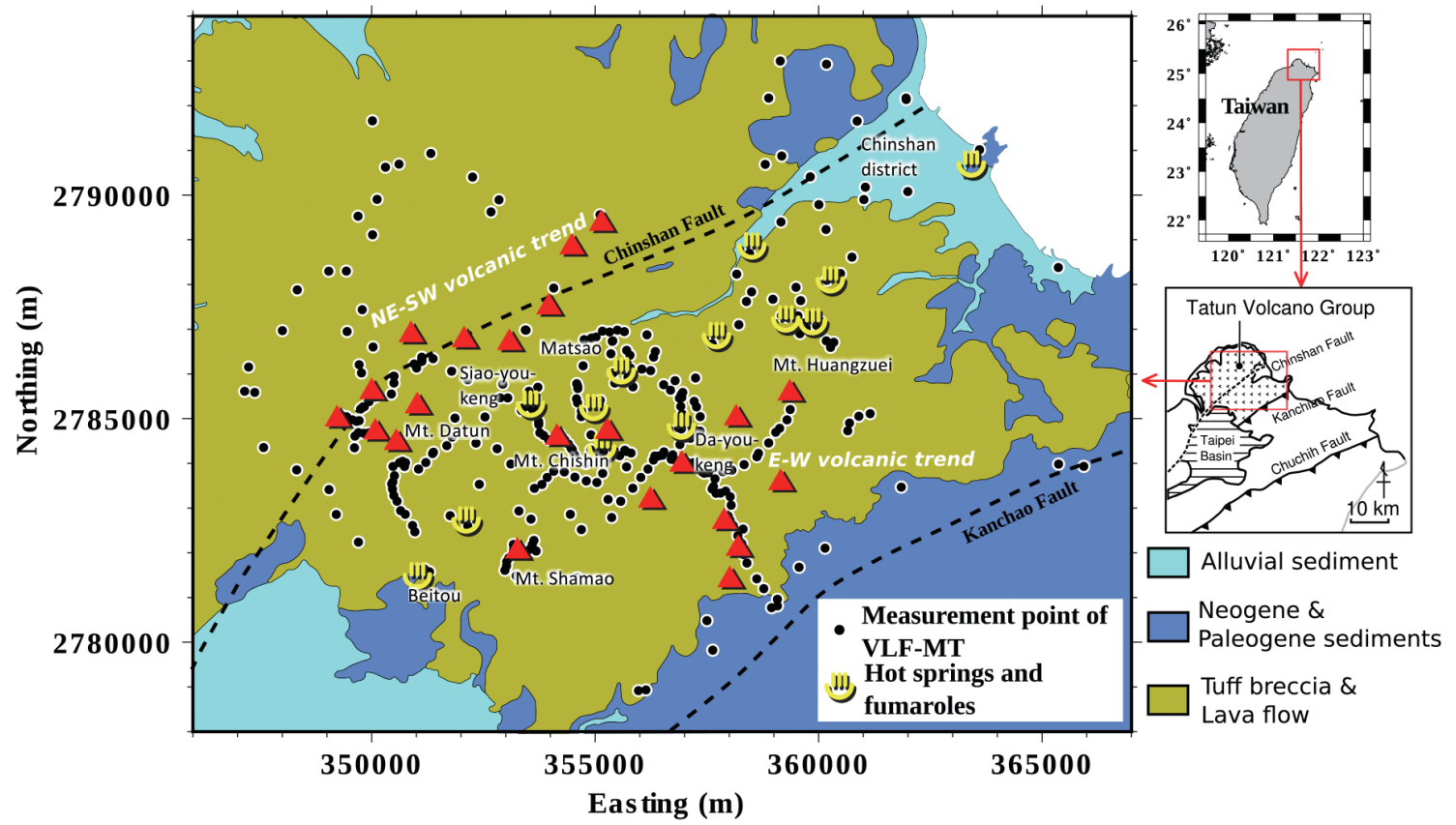

Fig. 1. Location map of the TVG, Northern Taiwan, showing representative geological features and mountain peaks. Andesitic lava of the TVG covers the northern tip of the island. VLF-MT measurement points are denoted by solid circles, while the mountain peaks are denoted by red triangles. 
performed using an electromagnetic wave with a singular frequency of $22.1 \mathrm{kHz}$, emitted by the Ebino VLF transmitter (Miyazaki Prefecture, Japan), approximately 1200 km away from the study area. The VL-101 equipment manufactured by Tierra Technica Ltd. was used as the receiver. An induction coil and two potential electrodes were deployed to measure the tangential magnetic field and the radial electric field, respectively. Notably, such a configuration is usually adopted in order to maintain a high signal to noise $(\mathrm{S} / \mathrm{N})$ ratio (Scott 1975). In addition, the phases were used to check the quality of the data, noting that most of their values (mean: $47^{\circ}$, standard deviation: $13^{\circ}$ ) were considered to be within the acceptable range.

Figure 1 shows the survey area and the survey points. A total of 324 measurements were carried out in 2009,2012, and 2013 in the mountain area of the TVG and additionally in the Chinshan District. The measurements were basically done along mountain roads, while avoiding artificial structures and power lines. It is noteworthy that there was no significant change in the volcanic activity during the period (Murase et al. 2014). The calculated resistivity data were analyzed by a geostatistical approach described below, in order to provide a spatial distribution of the resistivity.

\section{GEOSTATISTICAL DATA ANALYSIS}

Geostatistical techniques are used to statistically predict unsampled values of variables from known datasets, by considering their spatial correlation (Deutsch and Journel 1998). The techniques have been widely applied to various field data to estimate the spatial distribution of variables such as lithologies (Koike and Matsuda 2005), ore grades (Journel 1974; Chatterjee et al. 2010), pollutants (Atteia and Dubois 1994; McGrath et al. 2004), structural features such as crack density and its orientation (Koike et al. 2015), hydrological parameters such as permeability (Cassiani et al. 1998; Fairley et al. 2003; Heffner and Fairley 2006; Anderson and Fairley 2008), and others.

The spatial correlation of data can be expressed using the "Variogram", and is defined as (Deutsch and Journel 1998):

$\gamma=\frac{1}{2} \operatorname{Var}\{Z(\boldsymbol{u}+\boldsymbol{h})-Z(\boldsymbol{u})\} \quad \forall \boldsymbol{u}, \boldsymbol{u}+\boldsymbol{h} \in A$

where: $\gamma$ is the semivariogram, $\operatorname{Var}\{\}$ is the variance, $Z(\boldsymbol{u})$ and $Z(\boldsymbol{u}+\boldsymbol{h})$ are the random variables at the location $\boldsymbol{u}$ and $\boldsymbol{u}+\boldsymbol{h}$ within $A$, respectively. Under an assumption of data stationarity (Deutsch and Journel 1998), the variogram $\gamma$ is a function of the separation distance $\boldsymbol{h}$. In a case of small $\boldsymbol{h}$, the variables are expected to have good correlation, exhibiting a low value of $\gamma$, while a large $|\boldsymbol{h}|$ would give a high $\gamma$. Therefore, $\gamma$ allows us to evaluate the spatial continuity of the data values.

The present study used the indicator semivariogram defined as (Goovaerts 1997; Deutsch and Journel 1998):

$$
\begin{aligned}
& \gamma(\boldsymbol{h})=\frac{1}{2 N(\boldsymbol{h})} \sum_{i=1}^{N(\boldsymbol{h})}\left[I\left(u_{i}\right)-I\left(u_{i}+\boldsymbol{h}\right)\right]^{2} \\
& I\left(u_{i}\right)= \begin{cases}1, & \text { if } z\left(u_{i}\right) \leq C u t_{k} \\
0, & \text { otherwise }\end{cases}
\end{aligned}
$$

where: $N(\boldsymbol{h})$ is the number of data pairs, $I\left(u_{i}\right)$ is the indicator transform, $z\left(u_{i}\right)$ is the known value of the random variable $Z$ at the location $u_{i}$, and $C u t_{k}$ is the cutoff value. The indicator semivariogram is effective when extracting a specific characteristic, such as lithology, from numerical information (Shoji and Koike 2007; Koike and Shoji 2008). In the present study, nine cutoffs were defined in order to examine the relationship between data continuity and the spatial extent of surface geological features in the TVG.

Figures $2 \mathrm{a}$ - $\mathrm{i}$ show the experimental indicator semivariograms for each cutoff value, noting that the cutoff values correspond to the cumulative frequency " $p$ " of the resistivity shown in Fig. 2j. The variogram models are shown as the solid lines in the figures, while their parameters are given in Table 1, which were objectively obtained from the numerical code "AUTO-IK" (Goovaerts 2009). The accuracy and precision of the models are assured by the accuracy plot and the standardized PI-width plot, as shown in Figs. 2k and 1, respectively (see Goovaerts 2009). It was found that the last three cutoffs (320, 400, and $1000 \Omega \mathrm{m}$ ) have ranges, a proxy for the continuity of data, that are about three times as long as the first three cutoffs $(16,32$, and $40 \Omega \mathrm{m})$. This indicates that the conductive area has a smaller spatial extent than the resistive one. In fact, low resistivities $(<40 \Omega \mathrm{m})$ and high resistivities (>300 $\Omega \mathrm{m}$ ) were observed mostly at the hydrothermal phenomena and the edifice of the E-W volcanic trend, respectively. According to the geological investigations (MRSO 1971), the former has a spatial extent of several hundred meters to one kilometer, while the latter has a much larger spatial extent. Therefore, the modeled ranges are quite consistent with the geological features.

\section{STOCHASTIC SIMULATION}

The modeled variograms were used for an indicatorbased stochastic simulation processing, which is a tool to estimate the spatial distribution of variables by considering their uncertainties (Deutsch and Journel 1998). In the simulation, an indicator kriging estimates a conditional cumulative distribution function (CCDF) of an unsampled value, using known values of the adjacent points. The unsampled value is determined using the kriged CCDF and the cumulative probability selected by a Monte-Carlo method. The 

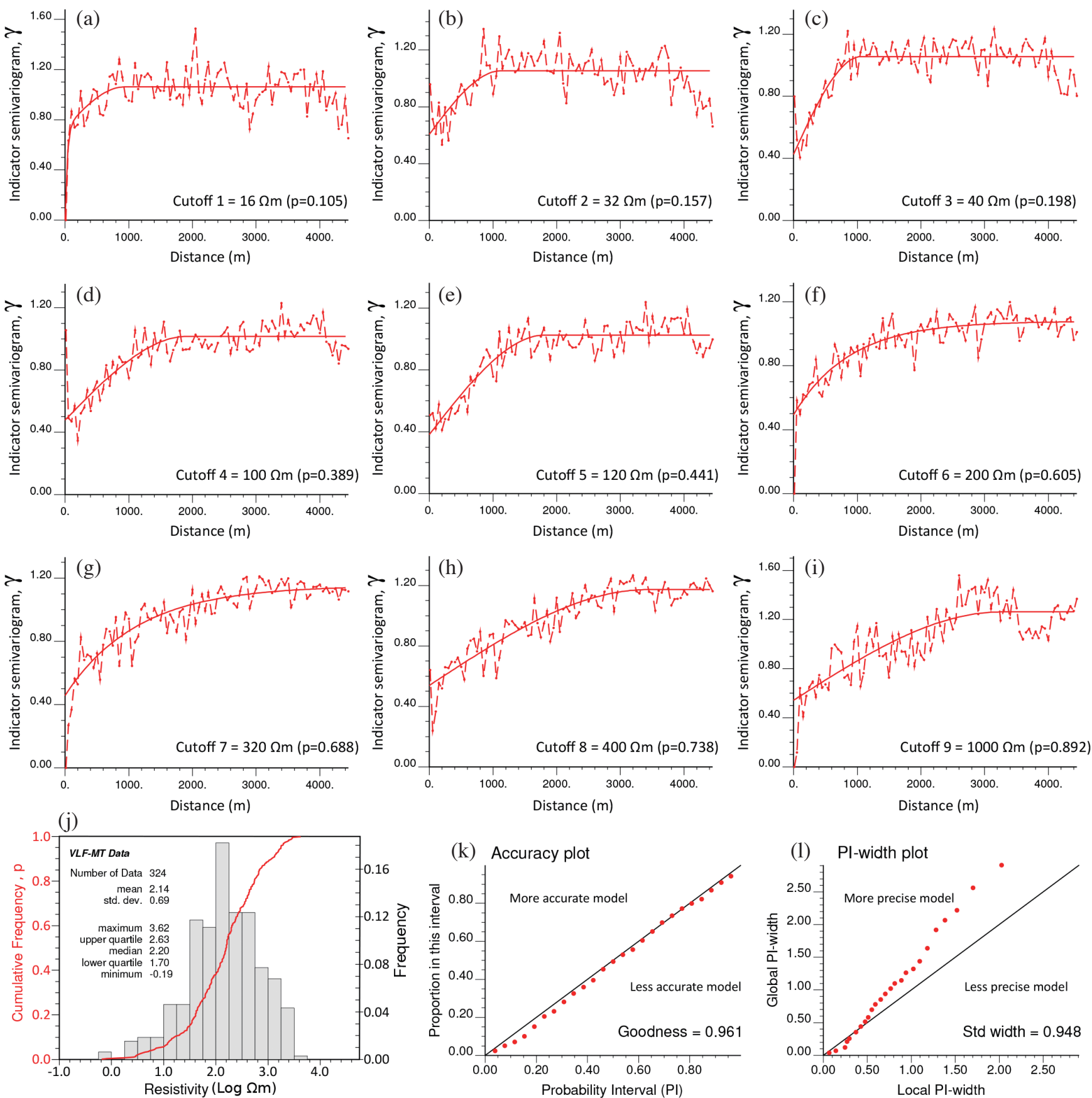

Fig. 2. Results of geostatistical data processing using the AUTO-IK program. (a) - (i) Indicator semivarigrams for each cutoff value. Broken and solid lines represent the experimental variograms from the VLF-MT data and the modeled variograms from Table 1, respectively. (j) Frequency distribution of the resistivity plotted as a histogram (grey bars) and as cumulative frequency " $p$ " (red line). (k) Result of the accuracy plot. (1) Result of the standardized PI-width plot. 
Table 1. Variogram Models of Resistivity Variability at the TVG.

\begin{tabular}{ccccc}
\hline Cutoff $(\mathbf{\Omega m})$ & Model Type & Nugget & Sill & Range $(\mathbf{m})$ \\
\hline $16(p=0.105)$ & Spherical & 0 & 0.3274 & 923 \\
& + Exponential & & 0.7344 & 103 \\
$32(p=0.157)$ & Spherical & 0.6062 & 0.4470 & 1120 \\
$40(p=0.198)$ & Spherical & 0.4266 & 0.6297 & 1059 \\
$100(p=0.389)$ & Spherical & 0.4780 & 0.5383 & 1920 \\
$120(p=0.441)$ & Spherical & 0.3808 & 0.6437 & 1819 \\
$200(p=0.605)$ & Exponential & 0.4919 & 0.5864 & 2630 \\
$320(p=0.688)$ & Exponential & 0.4572 & 0.6953 & 3388 \\
$400(p=0.738)$ & Spherical & 0.5386 & 0.6341 & 3430 \\
$1000(p=0.892)$ & Spherical & 0.5423 & 0.7200 & 3253 \\
\hline
\end{tabular}

determined value is used together with the other known values for estimating the next unknown values. By iterating the above processes, the spatial distribution of the variables is estimated. The program sisim in GSLIB (Deutsch and Journel 1998) was used for the analyses in the present study.

\section{RESULTS}

Figure 3a shows the estimated distribution of the resistivity, which was obtained from an average of 300 iterations of the simulation (called "E-type" estimation), while the topographical relief is overlain as contours. In the TVG, a high resistivity region $(\geq 300 \Omega \mathrm{m})$ is extending in E-W direction from Mt. Huangzuei, through Mt. Chishin, to Mt. Datun. On the other hand, the NE-SW volcanic trend has a moderate resistivity of $\sim 100 \Omega \mathrm{m}$. Several spots with low resistivity $(\leq 30 \Omega \mathrm{m})$ are distributed along valleys in the mountains, which correspond to hot spring and fumarolic areas, as denoted in Fig. 1. In the Chinshan District, low resistivities are aligned along the northern side of the Chinshan Fault, and are also present around the Chinshan hot spring area. In addition, the alluvial plain in the Chinshan District maintains resistivities in the range of $50-100 \Omega \mathrm{m}$. The variance map of the above simulations is shown in Fig. $3 b$, and could be useful for examining the relative reliability of the estimated resistivities. The variance tends to be small in areas where the surveys were densely performed. On the other hand, there are some blue-colored spots with relatively-large variances, corresponding to the presence of an abrupt change in the resistivity value.

Figure 4 shows a close-up map of the resistivity distribution focusing on an area of Mt. Chishin, which is overlain by lineaments and topographical features derived from a LiDAR digital elevation map (DEM) (Liu et al. 2007; Konstantinou et al. 2009; Belousov et al. 2010). Extremelyhigh resistivity areas $(\geq 1000 \Omega \mathrm{m})$ correspond to the lava of Mt. Chishin and Mt. Shamao, one of the youngest volcanic edifices in the TVG. Particularly in Mt. Chishin, the lava flowing in a S-E direction and the avalanche on the western flank are well traced by areas of high resistivity. In contrast, the lineament-bearing lava exhibit a resistivity of $\sim$ a few hundred $\Omega \mathrm{m}$. In the area of Siao-you-keng, extremely-low resistivities $(\leq 10 \Omega \mathrm{m})$ are present in the western rim of the crater, and correspond to active fumarolic areas. These are also present in the Beitou, Da-you-keng, and Matsao areas.

\section{DISCUSSION}

It is widely accepted that resistivity is significantly decreased by clay minerals, saline fluids and enhanced connectivity (i.e., high effective porosity) (Revil et al. 1998, 2002; Komori et al. 2010, 2013a). This section compares the resistivity map with previous geological and geophysical studies in order to examine the properties of the surface lithologies.

\subsection{Lavas in the TVG}

Lava of the E-W volcanic trend is characterized by resistivities higher than $1000 \Omega \mathrm{m}$, and is generally interpreted as fresh, dense volcanic rocks, which have low-porosity and minor clay content due to minimal alteration (Komori et al. 2013b). The result is consistent with the fact that the volcanic trend has a young age (Belousov et al. 2010). On the other hand, the lineament-bearing lava has lower resistivity, because lineaments increase the water content of the lava as well as its connectivity (Shankland and Waff 1974). Besides, weathering promotes the progressively increasing interaction of water and rock alteration that can result in the moderate resistivity of the lava in the NE-SW volcanic trend.

\subsection{Hydrothermal Phenomena in the TVG}

The low and extremely low resistivities in the hot spring and fumarolic areas are considered to be due to high temperature saline fluids and a large amount of clay minerals. In fact, the lowest resistivity of $0.5 \Omega \mathrm{m}$ was measured on the hot spring water in the area of Da-you-keng in the present study. Such low fluid resistivities are supported by several geochemical studies that report that the fluid has a high saline content ( 20000 ppm of TDS), high temperature $\left(\sim 80^{\circ} \mathrm{C}\right)$, and low $\mathrm{pH}(\sim 1)$ (CGS 2009). Furthermore, MRSO (1973) described the surface of the hydrothermal area as being composed of altered clays, including smectite and kaolinite. Therefore, the geological and geochemical aspects of the area can adequately explain the resistivity characteristics of the area.

In the TVG, Ohsawa et al. (2013) and Komori et al. (2014) considered that hydrothermal fluids mix with meteoric water in the shallow groundwater system during their ascent from depths, and then flow along topographical features. Therefore, the low resistivities observed along the valleys in 

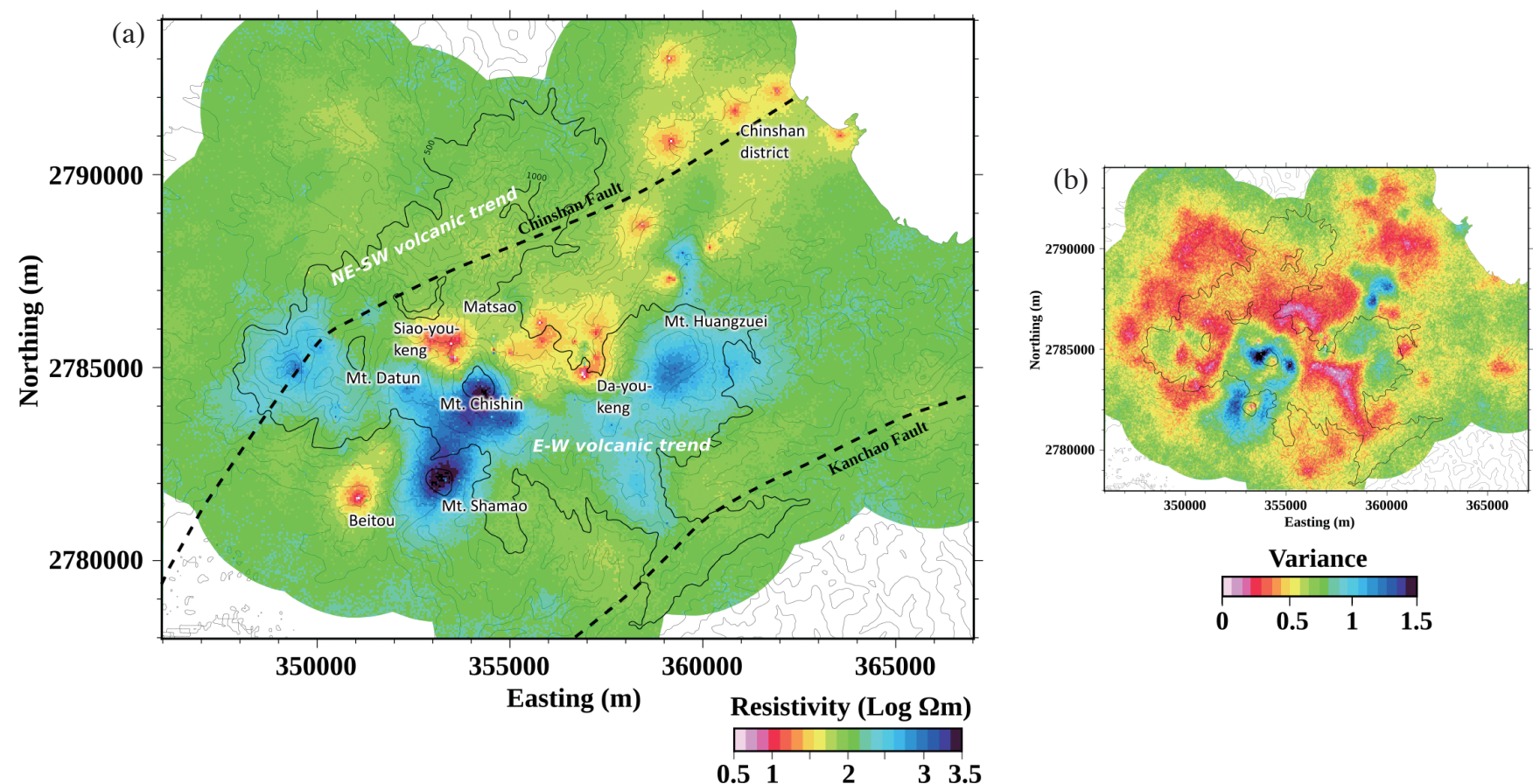

Fig. 3. Results of the geostatistical data analyses and indicator-based stochastic simulations. (a) Spatial distribution of the interpolated resistivity, with topographical relief shown by overlain contours. (b) Variance map of the simulations.

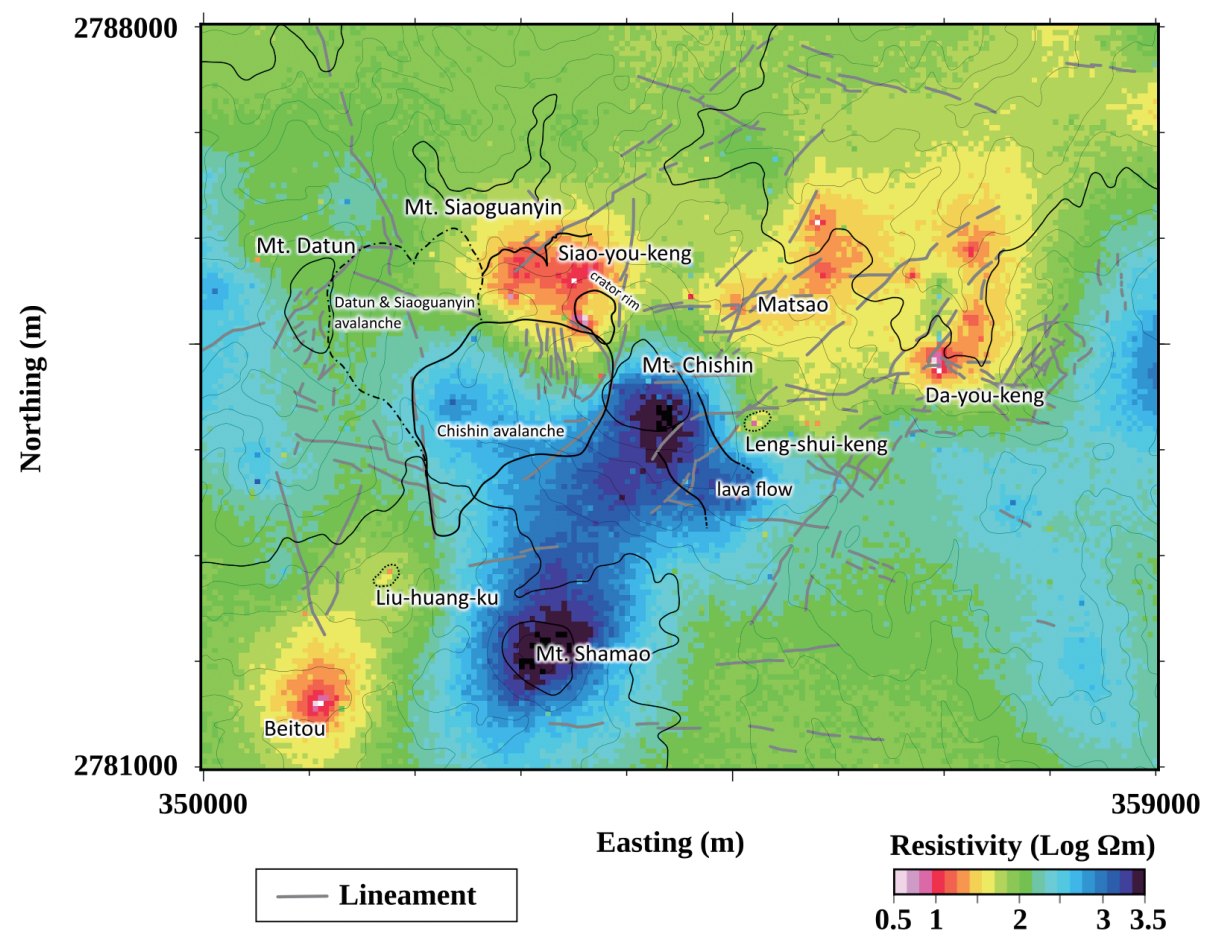

Fig. 4. Detail map of the resistivity distribution, focused on Mt. Chishin. Topographical features and lineaments traced from the LiDAR DEM are overlain on the distribution. 
the present study are considered to be due to the seepage of hot springs as a consequence of topography-driven flow.

\subsection{Chinshan District}

Yang and Chen (1989) performed detailed transient electromagnetic (TEM) surveys in the area around the Chinshan Fault, in order to reveal the distribution of onedimensional resistivity structures. The investigators showed that a sediment layer with a resistivity less than a few $\Omega m$ occurred at shallow depths on the northern side of the Chinshan fault, due to the southward-dipping normal faulting. In the present study, therefore, the low resistivities found on the northern side of the fault could be interpreted as conductive sediments.

\section{CONCLUSIONS}

Lineaments and rock alteration accompanying weathering and hydrothermal activity, commonly destabilize strata, causing landslides (Reid et al. 2001). In the present study, such properties in the rocks were successfully represented by resistivities of below a few hundred $\Omega \mathrm{m}$. Therefore, near-surface resistivity should allow us to identify hazardous areas in the TVG. On the basis of the spatial distribution of resistivity rendered here, further geophysical investigations, including electromagnetic observations with multiple frequencies and seismic reflection surveys, should reveal the shallow structural characteristics of the above hazards (Bichler et al. 2004; Chiang et al. 2015).

Today, airborne surveys are becoming the mainstream method of conducting surface investigations, by virtue of their capability to rapidly scan extensive tracts of the Earth's surface with high sampling densities (Siemon et al. 2009; Komazawa et al. 2010; Okuma et al. 2014). However, ground-based surveys are still the more robust tool, because they are overwhelmingly cost-effective and safe, and are barely affected by weather. We expect that our methodology and results can be used effectively for the mitigation of volcanic hazards in the TVG.

Acknowledgements We would like to thank the Yangmingshan National Park for arranging the surveys. We also thank Y.-H. Lee, R. Sih, C.-C. Lin, W. Minju (Academia Sinica) for supporting the surveys. We also thank J.P. Fairley (University of Idaho) for teaching geostatistical techniques, as well as Y. Iizuka, C.-H. Lin (Academia Sinica), S.-R. Song (National Taiwan University), K. Takemura, R. Yoshimura, (Kyoto University), Y. Mitsuhata, N. Matsushima, and H. Shinohara (Gelogical Survey of Japan, AIST) for valuable discussions. We also thank Editage (http://www.editage.jp) for English language editing. The manuscript was critically reviewed by two anonymous reviewers. Some figures were made using the GMT program (Wessel and Smith 1998).
This study was partly supported by Grants-in-Aid for Scientific Research (No. 21403003 and No. 23310120, T. Kagiyama) from the Ministry of Education, Culture, Sports, Science and Technology of Japan, and by a thematic research program application (AS-101-TP-A05, B.F. Chao) from the Academia Sinica, Taiwan. The authors declare that they have no competing interests.

\section{REFERENCES}

Anderson, T. R. and J. P. Fairley, 2008: Relating permeability to the structural setting of a fault-controlled hydrothermal system in southeast Oregon, USA. J. Geophys. Res., 113, B05402, doi: 10.1029/2007JB004962. [Link]

Atteia, O. and J. P. Dubois, 1994: Geostatistical analysis of soil contamination in the Swiss Jura. Environ. Pollut., 86, 315-327, doi: 10.1016/0269-7491(94)901724. [Link]

Belousov, A., M. Belousova, C. H. Chen, and G. F. Zellmer, 2010: Deposits, character and timing of recent eruptions and gravitational collapses in Tatun Volcanic Group, Northern Taiwan: Hazard-related issues. J. Volcanol. Geotherm. Res., 191, 205-221, doi: 10.1016/j. jvolgeores.2010.02.001. [Link]

Benderitter, Y. and A. Gérard, 1984: Geothermal study of Réunion Island: Audio-magnetotelluric survey. J. Volcanol.Geotherm.Res., 20,311-332, doi: 10.1016/03770273(84)90046-5. [Link]

Bichler, A., P. Bobrowsky, M. Best, M. Douma, J. Hunter, T. Calvert, and R. Burns, 2004: Three-dimensional mapping of a landslide using a multi-geophysical approach: The Quesnel Forks landslide. Landslides, 1, 29-40, doi: 10.1007/s10346-003-0008-7. [Link]

Cagniard, L., 1953: Basic theory of the magnetotelluric method of geophysical prospecting. Geophysics, 18, 605-635, doi: 10.1190/1.1437915. [Link]

Cassiani, G., G. Böhm, A. Vesnaver, and R. Nicolich, 1998: A geostatistical framework for incorporating seismic tomography auxiliary data into hydraulic conductivity estimation. J. Hydrol., 206, 58-74, doi: 10.1016/ S0022-1694(98)00084-5. [Link]

Central Geological Survey (CGS), 2009: $2^{\text {nd }}$ period of investigation and monitoring of particular geological hazard at Taipei district: investigation and monitoring of geological hazard and volcanic activity (2/4). Central Geological Survey, Taipei City, Taiwan. (in Chinese)

Chang, C. P., T. Y. Chang, J. Angelier, H. Kao, J. C. Lee, and S. B. Yu, 2003: Strain and stress field in Taiwan oblique convergent system: Constraints from GPS observation and tectonic data. Earth. Planet. Sci. Lett., 214, 115-127, doi: 10.1016/S0012-821X(03)00360-1. [Link]

Chang, P. Y., C. Chen, S. K. Chang, T. B. Wang, C. Y. 
Wang, and S. K. Hsu, 2012: An investigation into the debris flow induced by Typhoon Morakot in the Siaolin Area, Southern Taiwan, using the electrical resistivity imaging method. Geophys. J. Int., 188, 1012-1024, doi: 10.1111/j.1365-246X.2011.05310.x. [Link]

Chatterjee, S., S. Bandopadhyay, and D. Machuca, 2010: Ore grade prediction using a genetic algorithm and clustering based ensemble neural network model. Math. Geosci., 42, 309-326, doi: 10.1007/s11004-0109264-y. [Link]

Chen, A. and Y. T. Huang, 2014: Investigation of geothermal structures by electrical resistivity in Datun mountain area, Taiwan. 2014 meeting of Taiwan Geosciences Assembly, No. 1F-R-ER4-56.

Chen, C. H. and Y. J. Wu, 1971: Volcanic geology of the Tatun geothermal area, northern Taiwan. Proc Geol. Soc China, 14, 5-20.

Chen, C. S., 2009: Investigation of potential magma chambers beneath the Tatun volcanic area: Preliminary results of magnetotelluric survey. J. National Park, 19, 1-10. (in Chinese)

Chen, C. S., C. C. Chen, and K. Chou, 1998: Deep electrical structure of Taiwan as inferred from magnetotelluric observations. Terr. Atmos. Ocean. Sci., 9, 51-68, doi: 10.3319/TAO.1998.9.1.51(T). [Link]

Chen, C. T., J. C. Lee, Y. C. Chan, and C. Y. Lu, 2010: Growth normal faulting at the western edge of the metropolitan Taipei basin since the Last Glacial Maximum, northern Taiwan. Terr. Atmos. Ocean. Sci., 21, 409428, doi: 10.3319/TAO.2009.11.13.01(TH). [Link]

Chiang, C. W., H. L. Hsu, and C. C. Chen, 2015: An investigation of the $3 \mathrm{D}$ electrical resistivity structure in the Chingshui geothermal area, NE Taiwan. Terr. Atmos. Ocean. Sci., 26, 269-281, doi: 10.3319/ TAO.2014.12.09.01(T) [Link]

Deutsch, C. V. and A. G. Journel, 1998: GSLIB: Geostatistical Software Library and User's Guide ( $2^{\text {nd }} E d$.), Oxford University Press, New York, 369 pp.

Fairley, J., J. Heffner, and J. Hinds, 2003: Geostatistical evaluation of permeability in an active fault zone. Geophys. Res. Lett., 30, doi: 10.1029/2003GL018064. [Link]

Fitterman, D. V. and M. T. Stewart, 1986: Transient electromagnetic sounding for groundwater. Geophysics, 51, 995-1005, doi: 10.1190/1.1442158. [Link]

Goovaerts, P., 1997: Geostatistics for Natural Resources Evaluation, Oxford University Press, New York, $483 \mathrm{pp}$.

Goovaerts, P., 2009: AUTO-IK: A 2D indicator kriging program for the automated non-parametric modeling of local uncertainty in earth sciences. Comput. Geosci., 35, 1255-1270, doi: 10.1016/j.cageo.2008.08.014. [Link]

Heffner, J. and J. Fairley, 2006: Using surface characteristics to infer the permeability structure of an active fault zone. Sediment. Geol., 184, 255-265, doi: 10.1016/j. sedgeo.2005.11.019. [Link]

Jongmans, D. and S. Garambois, 2007: Geophysical investigation of landslides: a review. Bull. de la Société Géologique de France, 178, 101-112, doi: 10.2113/ gssgfbull.178.2.101. [Link]

Journel, A. G., 1974: Geostatistics for conditional simulation of ore bodies. Econ. Geol., 69, 673-687, doi: 10.2113/gsecongeo.69.5.673. [Link]

Koike, K. and S. Matsuda, 2005: Spatial modeling of discontinuous geologic attributes with geotechnical applications. Eng. Geo., 78, 143-161, doi: 10.1016/j. enggeo.2004.12.004. [Link]

Koike, K. and T. Shoji, 2008: Fundamentals and Applications of geostatistical simulation methods. J. Geotherm. Res. Soc. Japan, 30, 23-25. (in Japanese)

Koike, K., T. Kubo, C. Liu, A. Masoud, K. Amano, A. Kurihara, T. Matsuoka, and B. Lanyon, 2015: 3D geostatistical modeling of fracture system in a granitic massif to characterize hydraulic properties and fracture distribution. Tectonophysics, 660, 1-16, doi: 10.1016/j. tecto.2015.06.008. [Link]

Komazawa, M., S. Okuma, and J. Segawa, 2010: An integrated airborne gravity survey of an offshore area near the northern Noto Peninsula, Japan. Explor. Geophys., 41, 88-95.

Komori, S., T. Kagiyama, H. Hoshizumi, S. Takakura, and M. Mimura, 2010: Vertical mapping of hydrothermal fluids and alteration from bulk conductivity: Simple interpretation on the USDP-1 site, Unzen Volcano, SW Japan. J. Volcanol. Geotherm. Res., 198, 339-347, doi: 10.1016/j.jvolgeores.2010.09.019. [Link]

Komori, S., T. Kagiyama, S. Takakura, S. Ohsawa, M. Mimura, and T. Mogi, 2013a: Effect of the hydrothermal alteration on the surface conductivity of rock matrix: Comparative study between relatively-high and low temperature hydrothermal systems. J. Volcanol. Geotherm. Res., 264, 164-171, doi: 10.1016/j. jvolgeores.2013.08.009. [Link]

Komori, S., T. Kagiyama, M. Utsugi, H. Inoue, and I. Azuhata, 2013b: Two-dimensional resistivity structure of Unzen Volcano revealed by AMT and MT surveys. Earth Planets Space, 65, 759-766, doi: 10.5047/ eps.2012.10.005. [Link]

Komori, S., M. Utsugi, T. Kagiyama, H. Inoue, C. H. Chen, H. T. Chiang, B. F. Chao, R. Yoshimura, and W. Kanda, 2014: Hydrothermal system in the Tatun Volcano Group, northern Taiwan, inferred from crustal resistivity structure by audio-magnetotellurics. Prog. Earth Planet. Sci., 1, 1-14, doi: 10.1186/s40645-014-0020-7. [Link]

Konstantinou, K. I., C. H. Lin, W. T. Liang, and Y. C. Chan, 2009: Seismogenic stress field beneath the Tatun Volcano Group, northern Taiwan. J. Volcanol. 
Geotherm. Res., 187, 261-271, doi: 10.1016/j. jvolgeores.2009.09.011. [Link]

Lee, H. F., T. F. Yang, T. F. Lan, S. R. Song, and S. Tsao, 2005: Fumarolic gas composition of the Tatun Volcano Group, northern Taiwan. Terr. Atmos. Ocean. Sci., 16, 843-864, doi: 10.3319/TAO.2005.16.4.843(GIG). [Link]

Liu, C. M., S. R. Song, Y. L. Chen, and S. Tsao, 2011: Characteristics and origins of hot springs in the Tatun Volcano Group in northern Taiwan. Terr. Atmos. Ocean. Sci., 22, 475-489, doi: 10.3319/TAO.2011.05.25.01(TT). [Link]

Liu, J. K., Y.C. Chan, T. Y. Shih, and Y.C. Hsieh, 2007: Lidar DEM for characterizing the volcanic landforms of Tatun volcanoes in metropolitan Taipei. IGARSS, 2007, 3752-3755, doi: 10.1109/IGARSS.2007.4423659. [Link]

McGrath, D., C. Zhang, and O. T. Carton, 2004: Geostatistical analyses and hazard assessment on soil lead in Silvermines area, Ireland. Environ. Pollut., 127, 239-248, doi: 10.1016/j.envpol.2003.07.002. [Link]

Mining Research and Service Organization (MRSO), 1969: The geothermal exploration of the, Tatun Volcano Group (I). MRSO Report, No. 90, Mining Research and Service Organization, Taipei City, Taiwan. (in Chinese)

Mining Research and Service Organization (MRSO), 1970: The geothermal exploration of the Tatun Volcano Group (II). MRSO Report, No. 102, Mining Research and Service Organization, Taipei City, Taiwan. (in Chinese)

Mining Research and Service Organization (MRSO), 1971: The geothermal exploration of the, Tatun Volcano Group (III). MRSO Report, No. 111, Mining Research and Service Organization, Taipei City, Taiwan. (in Chinese)

Mining Research and Service Organization (MRSO), 1973: The geothermal exploration of the, Tatun Volcano Group (IV). MRSO Report, No. 126, Mining Research and Service Organization, Taipei City, Taiwan. (in Chinese)

Murase, M., C. H. Lin, F. Kimata, H. Mori, and H. C. $\mathrm{Pu}, 2014$ : Volcano-hydrothermal activity detected by precise levelling surveys at the Tatun volcano group in Northern Taiwan during 2006-2013. J. Volcanol. Geotherm. Res., 286, 30-40, doi: 10.1016/j. jvolgeores.2014.09.001. [Link]

Ogawa, Y., N. Matsushima, H. Oshima, S. Takakura, M. Utsugi, K. Hirano, M. Igarashi, and T. Doi, 1998: A resistivity cross-section of Usu volcano, Hokkaido, Japan, by audiomagnetotellurics soundings. Earth Planets Space, 50, 339-346, doi: 10.1186/BF03352120. [Link]

Ohba, T., T. Sawa, N. Taira, T. F. Yang, H. F. Lee, T. F. Lan, M. Ohwada, N. Morikawa, and K. Kazahaya,
2010: Magmatic fluids of Tatun volcanic group, Taiwan. Appl. Geochem., 25, 513-523, doi: 10.1016/j.apgeochem.2010.01.009. [Link]

Ohsawa, S., H. F. Lee, B. Liang, S. Komori, C. H. Chen, and T. Kagiyama, 2013: Geochemical characteristics and origins of acid hot spring waters in Tatun Volcanic Group, Taiwan. J. Hot Spring Sci., 62, 282-293. (in Japanese)

Okuma, S., T. Nakatsuka, and Y. Ishizuka, 2014, Aeromagnetic constraints on the subsurface structure of Usu Volcano, Hokkaido, Japan. Explor. Geophys., 45, 2436, doi: 10.1071/eg13041. [Link]

Reid, M. E., T. W. Sisson, and D. L. Brien, 2001: Volcano collapse promoted by hydrothermal alteration and edifice shape, Mount Rainier, Washington. Geology, 29, 779-782, doi: 10.1130/0091-7613(2001)029<0779:VC PBHA $>2.0 . C O ; 2$. $[\underline{\text { Link }}]$

Revil, A., L. M. Cathles III, S. Losh, and J. A. Nunn, 1998: Electrical conductivity in shaly sands with geophysical applications. J. Geophys. Res., 103, 23925-23936, doi: 10.1029/98JB02125. [Link]

Revil, A., D. Hermitte, E. Spangenberg, and J. J. Cocheme, 2002: Electrical properties of zeolitized volcaniclastic materials. J. Geophys. Res., 107, doi: 10.1029/2001JB000599. [Link]

Scott, W. J., 1975: VLF Resistivity (Radiohm) Survey, Agricola Lake area, District of Mackenzie. Report of Activities, Part A, April to October 1974, Geological Survey of Canada Paper, No. 75-1A, 223-225.

Shankland, T. J. and H. S. Waff, 1974: Conductivity in fluid-bearing rocks. J. Geophys. Res., 79, 4863-4868, doi: 10.1029/JB079i032p04863. [Link]

Shoji, T. and K. Koike, 2007: Kriging - Estimation of spatial data taking account of error. J. Geotherm. Res. Soc. Japan, 29, 183-194. (in Japanese)

Shyu, J. B. H., K. Sieh, Y. G. Chen, and C. S. Liu, 2005: Neotectonic architecture of Taiwan and its implications for future large earthquakes. J. Geophys. Res., 110, B08402, doi: 10.1029/2004JB003251. [Link]

Siemon, B., A. V. Christiansen, and E. Auken, 2009: A review of helicopter-borne electromagnetic methods for groundwater exploration. Near Surf. Geophys., 7, 629646, doi: 10.3997/1873-0604.2009043. [Link]

Simpson, F. and K. Bahr, 2005: Practical Magnetotellurics, Cambridge University Press, Cambridge, 245 pp, doi: 10.1017/CBO9780511614095. [Link]

Stanley, W. D., D. B. Jackson, and A. A. R. Zohdy, 1976: Deep electrical investigations in the Long Valley Geothermal Area, California. J. Geophys. Res., 81, 810820, doi: 10.1029/JB081i005p00810. [Link]

Tabbagh, A., Y. Benderitter, P. Andrieux, J. P. Decriaud, and R. Guerin, 1991: VLF resistivity mapping and verticalization of the electric field. Geophys. Prospect., 39, 1083-1097, doi: 10.1111/j.1365-2478.1991. 
tb00360.x. [Link]

Vozoff, K., 1991: The magnetotelluric method. In: Nabighian, M. N. (Ed.), Electromagnetic Methods in Applied Geophysics, Society of Exploration Geophysicists, Oklahoma, 641-711.

Wang, K. L., S. L. Chung, C. H. Chen, R. Shinjo, T. F. Yang, and C. H. Chen, 1999: Post-collisional magmatism around northern Taiwan and its relation with opening of the Okinawa Trough. Tectonophysics, 308, 363-376, doi: 10.1016/S0040-1951(99)00111-0. [Link]

Wang, W. H. and C. H. Chen, 1990: The volcanology and fission track age dating of pyroclastic deposits in Tatun Volcano Group, northern Taiwan. Acta Geol. Taiwan, 28, 1-30.

Waters, K. H., 1987: Reflection Seismology: A Tool for Energy Resource Exploration, Wiley, New York, U.S., 377 pp.

Wessel, P. and W. H. F. Smith, 1998: New, improved version of generic mapping tools released. Eos Trans.
$A G U, 79$, doi: 10.1029/98EO00426. [Link]

Yamaguchi, S., T. Murakami, and H. Inokuchi, 2001: Resistivity mapping using the VLF-MT method around surface fault ruptures of the 1995 Hyogo-ken Nanbu earthquake, Japan. Island Arc, 10, 296-305, doi: 10.1111/j.1440-1738.2001.00328.x. [Link]

Yang, C. H. and C. S. Chen, 1989: Application of the TEM method in the Chinshan fault area, Chinshan, Taiwan, Proc. Geol. Soc. China, 32, 369-381.

Yang, T. F., Y. Sano, and S. R. Song, 1999: 3He/4He ratios of fumaroles and bubbling gases of hot springs in Tatun Volcano Group, North Taiwan. Il Nuovo Cimento C, 22, 281-286.

Yang, T.F., C.H.Chen, R.L. Tien, S. R.Song, and T.K.Liu, 2003: Remnant magmatic activity in the Coastal Range of East Taiwan after arc-continent collision: fissiontrack data and $3 \mathrm{He} / 4 \mathrm{He}$ ratio evidence. Radiat. Meas., 36, 343-349, doi: 10.1016/S1350-4487(03)00149-5. [Link] 